\title{
A Pathological Study of Acute Pulmonary Toxicity Induced by Inhaled Kanto Loam Powder
}

\author{
Yoshimi Kobayashi ${ }^{1}$, Akinori Shimada ${ }^{2, *}$, Takehito Morita ${ }^{1}$, Kenichiro Inoue ${ }^{3}$ and \\ Hirohisa Takano $^{4}$ \\ 1 Department of Veterinary Pathology, Tottori University, 4-101 Koyama Minami, Tottori-shi, Tottori 680-8553, \\ Japan; guildmiyoshi@yahoo.co.jp (Y.K.); morita@muses.tottori-u.ac.jp (T.M.) \\ 2 Laboratory of Pathology, School of Life and Environmental Science, Azabu University, 1-17-71 Fuchinobe, \\ Sagamihara-shi, Kanagawa 252-5201, Japan \\ 3 School of Nursing, University of Shizuoka, Shizuoka-shi, Shizuoka 422-8526, Japan; \\ inoue-k@u-shizuoka-ken.ac.jp \\ 4 Department of Environmental Engineering, Kyoto University Graduate School of Engineering, Kyoto-shi, \\ Kyoto 615-8530, Japan; takano.hirohisa.4x@kyoto-u.ac.jp \\ * Correspondence: a-shimada@azabu-u.ac.jp; Tel.: +81-042-754-7111
}

Received: 15 January 2018; Accepted: 30 January 2018; Published: 31 January 2018

\begin{abstract}
The frequency and volume of Asian sand dust (ASD) (Kosa) are increasing in Japan, and it has been reported that ASD may cause adverse respiratory effects. The pulmonary toxicity of ASD has been previously analyzed in mice exposed to ASD particles by intratracheal instillation. To study the pulmonary toxicity induced by inhalation of ASD, ICR mice were exposed by inhalation to 50 or $200 \mathrm{mg} / \mathrm{m}^{3}$ Kanto loam powder, which resembles ASD in elemental composition and particle size, for $6 \mathrm{~h}$ a day over 1, 3, 6, 9, or 15 consecutive days. Histological examination revealed that Kanto loam powder induced acute inflammation in the whole lung at all the time points examined. The lesions were characterized by infiltration of neutrophils and macrophages. The intensity of the inflammatory changes in the lung and number of neutrophils in both histological lesions and bronchoalveolar lavage fluid (BALF) appeared to increase over time. Immunohistochemical staining showed interleukin (IL)-6- and tumor necrosis factor (TNF)- $\alpha$-positive macrophages and a decrease in laminin positivity in the inflammatory lesions of the lung tissues. Electron microscopy revealed vacuolar degeneration in the alveolar epithelial cells close to the Kanto loam particles. The nitric oxide level in the BALF increased over time. These results suggest that inhaled Kanto loam powder may induce diffuse and acute pulmonary inflammation, which is associated with increased expression of inflammatory cytokines and oxidative stress.
\end{abstract}

Keywords: Asian sand dust; inhalation; Kanto loam powder; pulmonary toxicity

\section{Introduction}

Asian sand dust (ASD) (known as Kosa aerosol) originating from the arid deserts of Mongolia and China, causes severe air pollution annually in the Asia-Pacific area, including China, Korea, and Japan [1,2]. Epidemiological studies of ASD show that human exposure to ambient ASD particles is associated with an increase in pulmonary and cardiovascular problems and an increase in daily mortality in Korea [3,4], Taiwan [5], and Japan [6,7]. The frequency and scale of dust events giving rise to ASD aerosols have increased rapidly in the east Asian region since 2000 [8]. Due to recent environmental changes, humans are at an increased risk of exposure to ASD and the resultant adverse health effects on the respiratory system [9].

A previous study [10] reported that the major mineralogical component of ASD is silica $\left(\mathrm{SiO}_{2}\right)$. Occupational exposure to crystalline silica is associated with silicosis, lung cancer, pulmonary 
tuberculosis, and chronic obstructive pulmonary disease [11]. Moreover, silicosis patients often develop autoimmune diseases [12-14]. It has been reported that experimental chronic intratracheal exposure to crystalline silica causes granuloma formation and/or fibrosis in rats [15-18]. In addition, granulomatous inflammation, which is characterized by the accumulation of epithelioid macrophages containing crystalline silica particles, has been reported in the pulmonary lymph nodes of rats exposed by inhalation to crystalline silica $[19,20]$; lymph node silicosis was also reported in miners with prolonged silica exposure [21].

Intratracheal instillation of high doses of ASD produced acute [22,23] and chronic [24,25] inflammatory changes in the lung tissues. The chronic changes were similar to those caused by silica exposure and consisted of a focal infiltration of lymphocytes with an accumulation of epithelioid macrophages, granuloma formation in the lung, and aggregation of particle-containing macrophages in the pulmonary lymph nodes at two and three months after instillation. These findings suggest that precautions for the prevention of ASD exposure are required for the protection of public health and that experimental studies of ASD toxicity after inhalation are necessary.

The purpose of this study was to describe the acute lung toxicity induced by the inhalation of Kanto loam powder, which resembles ASD in elemental composition and particle size, in mice.

\section{Results}

\subsection{Gross Findings in the Lungs}

There were no gross changes in the lungs at $1,3,6,9$, or 15 days after exposure to either 50 or $200 \mathrm{mg} / \mathrm{m}^{3}$ of Kanto loam powder.

\subsection{Histopathology of the Lungs}

Lungs from control mice showed no pathological changes (Figure 1).

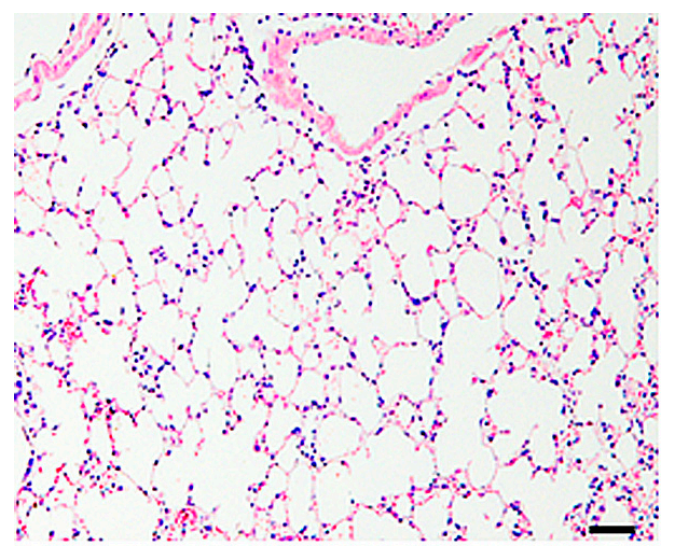

Figure 1. Histological findings of the control lungs, showing no changes. HE. Bar $=50 \mu \mathrm{m}$.

In the lungs from all of the particle-treated mice, diffuse deposition of the particles and acute inflammatory changes were observed, and the intensity of the inflammatory changes appeared to increase over time and with increasing particle concentration (Figure 2A-J). We observed infiltration of neutrophils into the alveolar space (Figure 3B), an increase in the number of macrophages containing cytoplasmic particles (Figure 3B), and intra-alveolar hemorrhage and the exudation of serum protein into the alveolar spaces (Figure 3B). Macrophages with increased cytoplasm were observed in the lungs of the mice treated with $50 \mathrm{mg} / \mathrm{m}^{3}$ of the particles for 15 days (Figure 3C) and in the lungs of the mice treated with $200 \mathrm{mg} / \mathrm{m}^{3}$ of the particles for 6,9 , and 15 days (Figure 3D). 


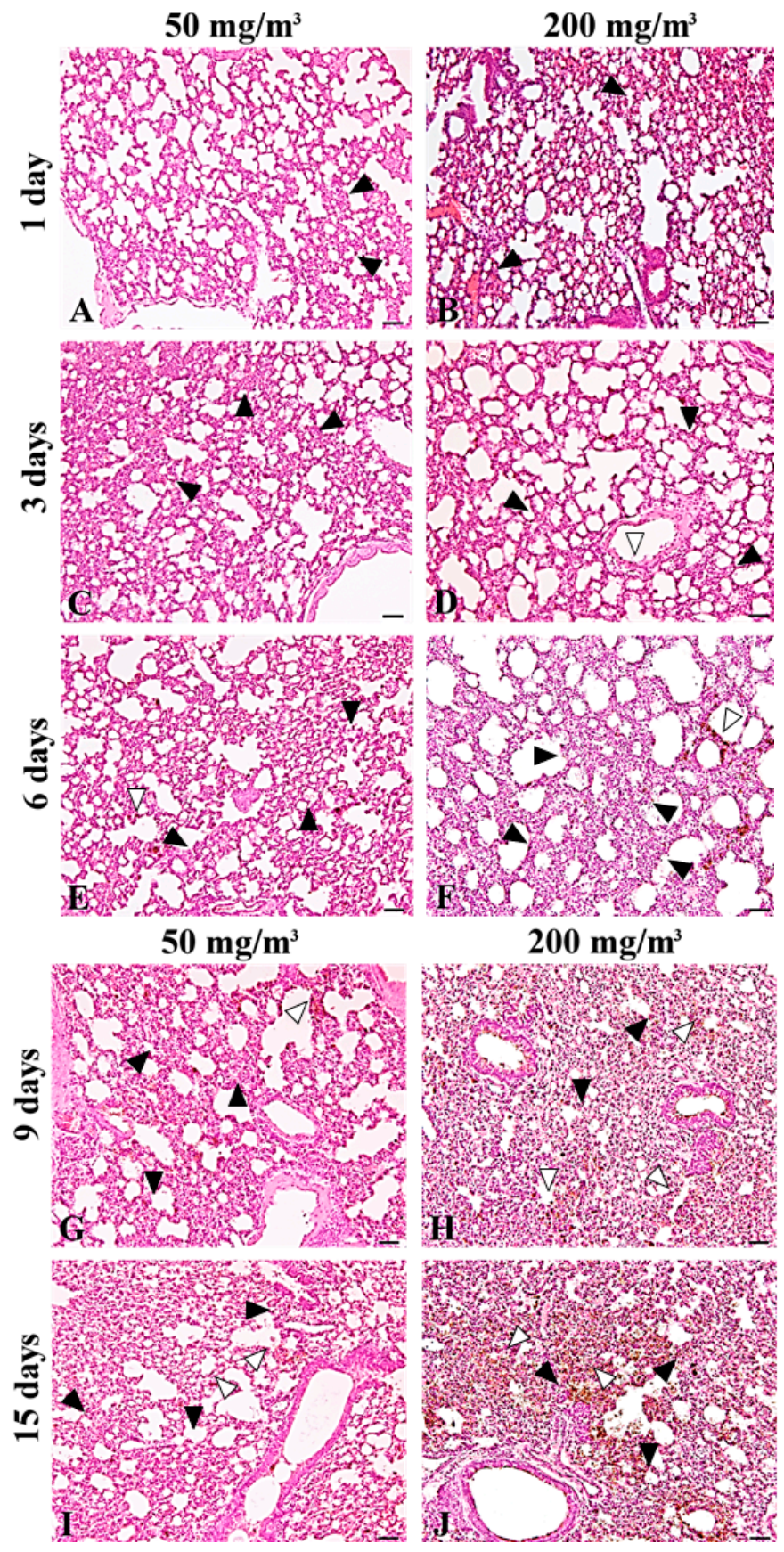

Figure 2. Histological examination of the lung taken from mice treated with Kanto loam powder showed acute inflammatory changes. Representative lung sections taken from mice treated with $50 \mathrm{mg} / \mathrm{m}^{3}$ of the powder at one day (A); three days (C); six days (E); nine days (G); and 15 days (I) after exposure, and from mice treated with $200 \mathrm{mg} / \mathrm{m}^{3}$ Kanto loam powder at one day (B); three days (D); six days (F); nine days (H); and 15 days (J) after exposure. Diffuse deposition of the particles (white arrowheads) at the bronchial mucosa and alveolar wall, and infiltration of inflammatory cells (neutrophils and macrophages) (black arrowheads) in the alveolar wall and alveolar space are observed; these changes become prominent with both time and concentration of the particles. HE. Bars $=50 \mu \mathrm{m}$. 


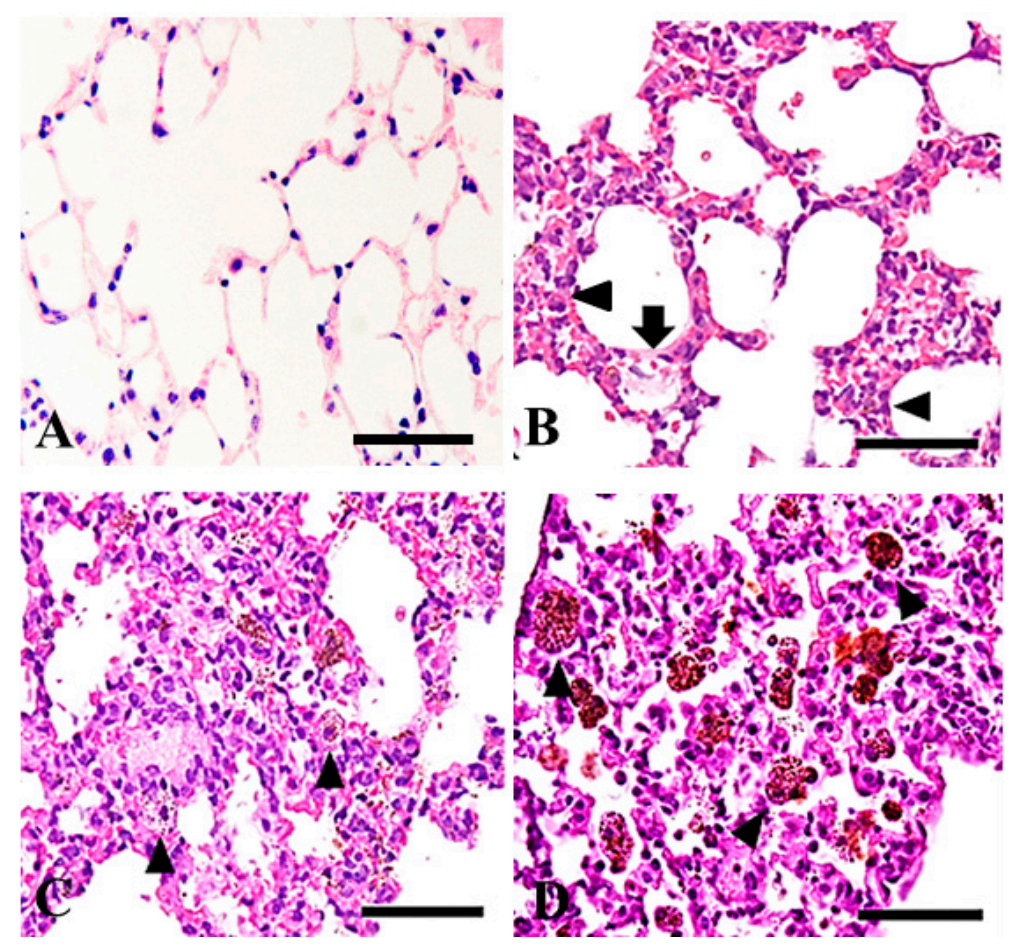

Figure 3. Higher power magnification of the histological findings of the control lungs (A); of mice treated with $50 \mathrm{mg} / \mathrm{m}^{3}$ of the powder for one day (B); treated for 15 days $(\mathbf{C})$; of mice treated with $200 \mathrm{mg} / \mathrm{m}^{3}$ of the powder for 15 days (D). Infiltration of neutrophils into alveoli and increased number of macrophages (black arrowheads), and exudation of serum protein in the alveolar space (black arrow) (B). Macrophages with increased cytoplasm containing the particles are shown (black arrow heads) (C,D). HE. Bars $=50 \mu \mathrm{m}$.

\subsection{Histopathology of the Pulmonary Lymph Nodes}

Pulmonary lymph nodes from control mice showed no pathological changes.

In the pulmonary lymph nodes taken from all of the particle-treated mice, an increased number of particle-containing neutrophils and macrophages were observed in the lymphatic sinus (Figure 4).

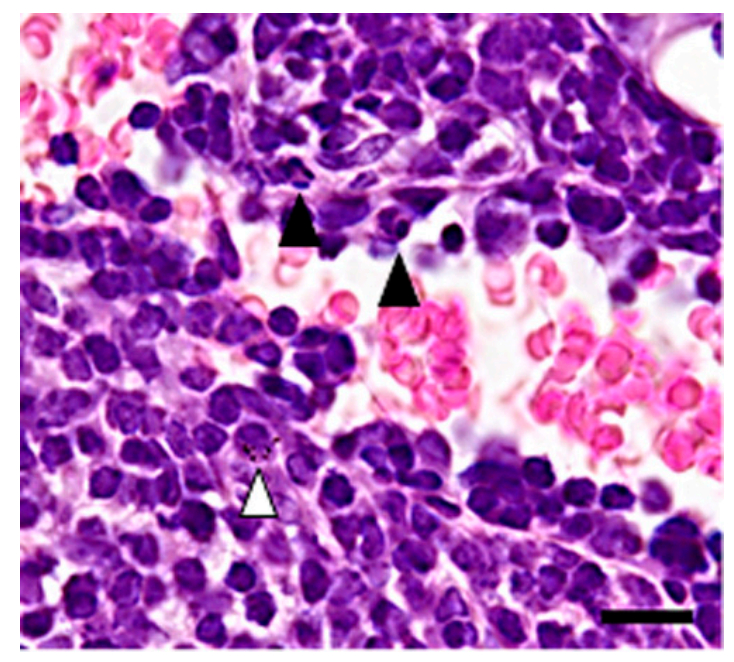

Figure 4. Histological changes of the lymph nodes taken from mice treated with $50 \mathrm{mg} / \mathrm{m}^{3}$ of the powder for one day. Increased number of neutrophils (black arrowheads) and a macrophage containing the particles in the sinus (a white arrowhead). HE. Bar $=50 \mu \mathrm{m}$. 


\subsection{Immunohistochemistry of the Lung}

\subsection{1. $\alpha$-SMA}

Alpha-SMA-positive spindle-shaped cells were observed in the lungs of the mice treated with $50 \mathrm{mg} / \mathrm{m}^{3}$ of the particles at 15 days after exposure, exclusively (Figure 5B).

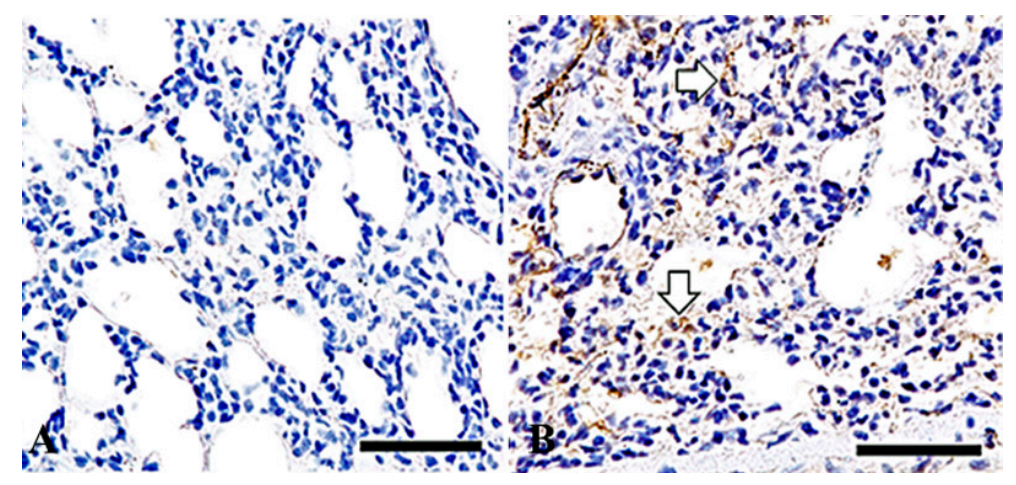

Figure 5. Alpha-SMA immunohistochemistory in the lungs of mice treated with $50 \mathrm{mg} / \mathrm{m}^{3}$ of the powder for one day (A) and treated for 15 days (B). Spindle-shaped to elongated cells in the inflammatory lesions show positive immunolabelings for $\alpha$-smooth muscle actin ((B), white arrows). Bars $=50 \mu \mathrm{m}$

\subsubsection{Laminin}

In the control lung tissue, laminin staining revealed continuous, distinct thin lines in the basement membranes of the bronchioles, alveolar walls, and blood vessels (Figure 6A). Reduced laminin positivity was observed in the basement membranes of the alveolar walls in the inflammatory lesions in the lungs of the particle-treated mice (Figure 6B).

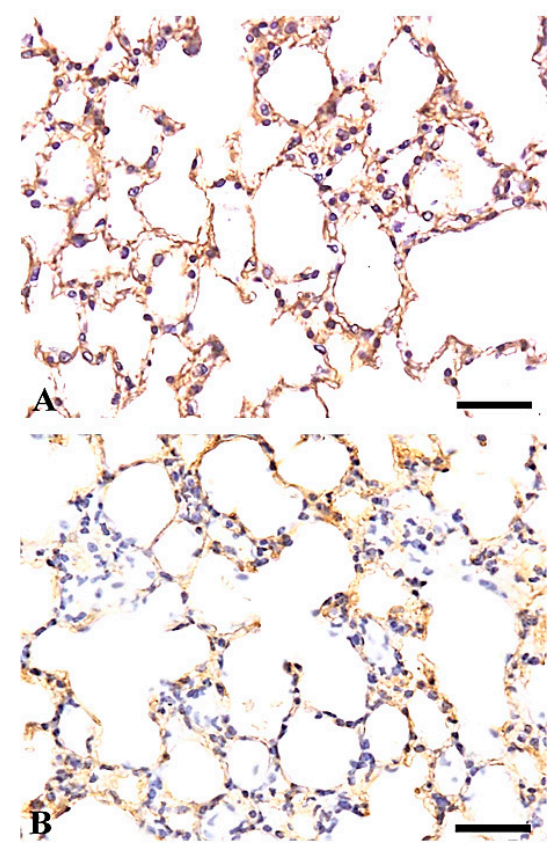

Figure 6. Laminin immunohistochemistry in the lungs of control mice (A) and of mice treated with $50 \mathrm{mg} / \mathrm{m}^{3}$ of the powder for one day (B). Positive, continuous, distinct thin lines are shown in the basement membrane of the alveoli (A). Weakly positive discontinuous staining is shown in the basement membrane of the alveoli in the inflammatory lesions (B). Bars $=30 \mu \mathrm{m}$. 


\subsubsection{TNF- $\alpha$, IL-6, and iNOS}

The cytoplasm of macrophages, which were lysozyme-positive [26], in the inflammatory lesions of the particle-treated mice stained positively for TNF- $\alpha$, IL-6 and iNOS (Figure 7a). Semi-quantitative analysis revealed a larger number of TNF- $\alpha$, IL-6, and iNOS positive macrophages in the lungs of mice treated with $200 \mathrm{mg} / \mathrm{m}^{3}$ of the powder (Figure $7 \mathrm{~b}$ ).

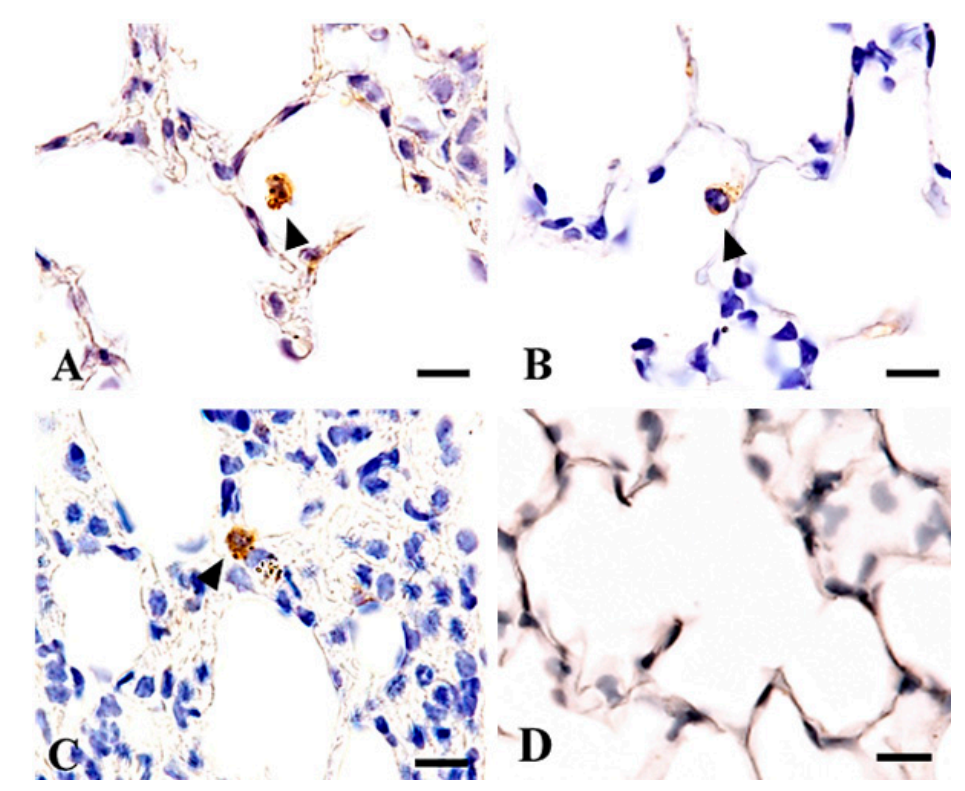

(a)

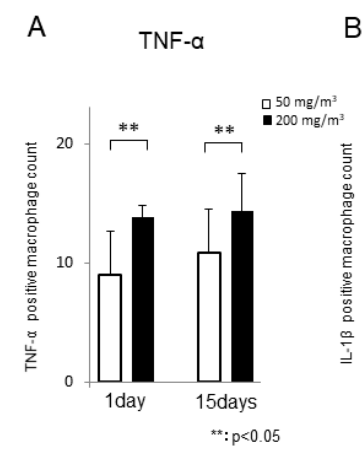

B

C inOS
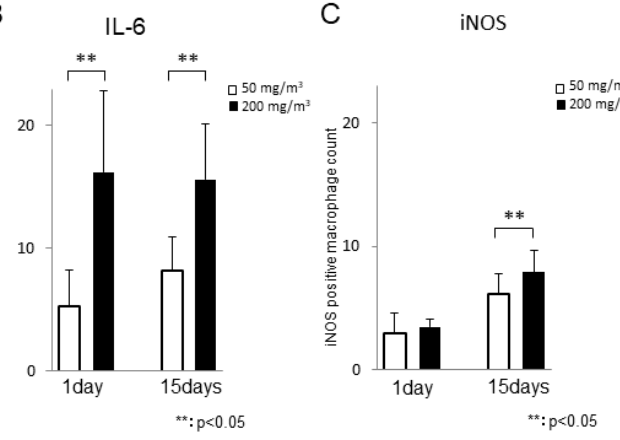

(b)

Figure 7. (a) TNF- $\alpha$ (A), IL-6 (B), and iNOS (C) immunohistochemistry of the lungs of mice treated with $50 \mathrm{mg} / \mathrm{m}^{3}$ of the powder for one day. Macrophages containing the brown particles show positive immunoreactivity for TNF- $\alpha$, IL-6, and iNOS (black arrowheads). Control (lungs of mice with no treatment, TNF- $\alpha$ ) (D). Bars $=10 \mu \mathrm{m}$. (b) A semi-quantative analysis of the immunohistochemical reactions (A: TNF- $\alpha$, B: IL-6, C: iNOS) in the lungs of mice treated with $50 \mathrm{mg} / \mathrm{m}^{3}$ (open bars) and $200 \mathrm{mg} / \mathrm{m}^{3}$ (filled bars) of the powder for one day and for 15 days $(* *<0.05)$.

\subsection{Electron Microscopy Analysis}

In the lungs of the mice treated with $50 \mathrm{mg} / \mathrm{m}^{3}$ of the powder for three days, destruction of the alveolar walls and epithelial cells exhibiting vacuolar degeneration were observed in the inflammatory lesions (Figure 8). 


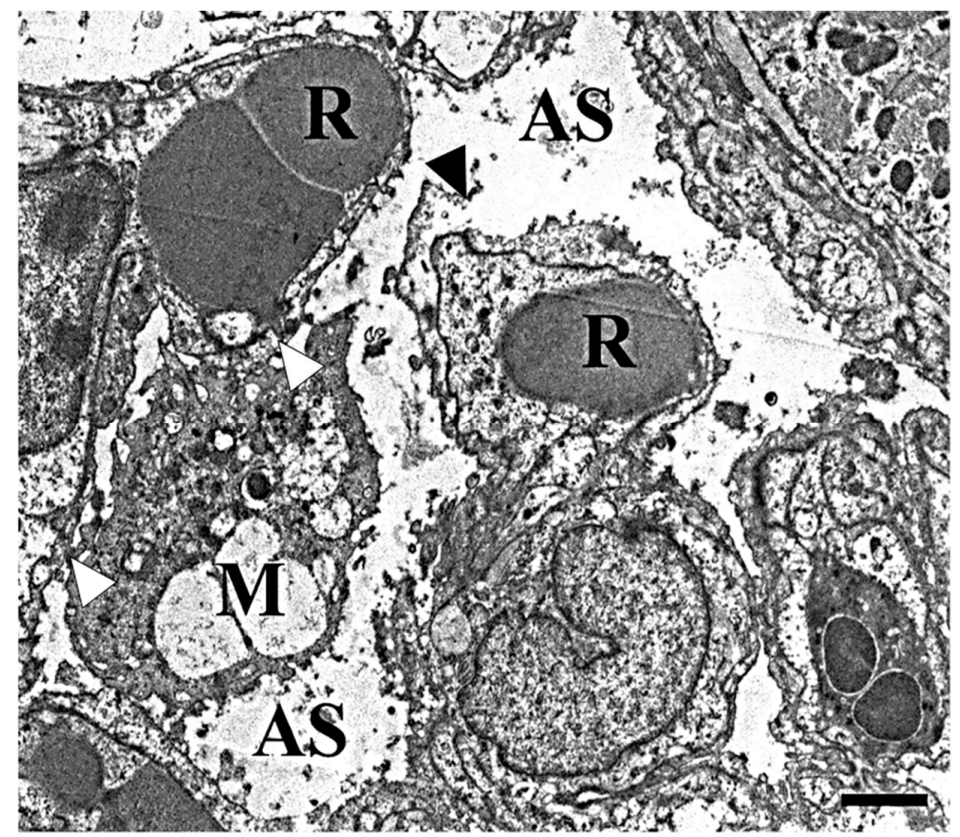

Figure 8. Transmission electron microscopic images of the inflammatory lesions in the lung from mice treated with $50 \mathrm{mg} / \mathrm{m}^{3}$ of the powder for three days. Destruction of the alveolar walls (black arrowhead) with epithelial cells showing vacuolar degeneration was observed in the inflammatory lesions. Note that the macrophage containing the particles is closely located to the alveolar wall (white arrowheads). AS: alveolar space, R: red blood cell, M: macrophage. Bar $=1 \mu \mathrm{m}$.

\subsection{Cytology and Measurement of $N O$ in the BALF}

The cytology results and NO measurements in the BALF are described in Figure 9. Significant changes in the BALF total cell numbers were not observed in the mice from any group, including the control group (Figure 9A). However, an increase in the number of BALF neutrophils was observed after the treatment (Figure 9). The percentage of neutrophils appeared to increase with the increasing number of exposure days after treatment in both the groups treated with $50 \mathrm{mg} / \mathrm{m}^{3}$ and $200 \mathrm{mg} / \mathrm{m}^{3}$ of the powder (Figure 9B). The percentage of neutrophils increased steeply to $40 \%$ at six days after the treatment, and then decreased to $20 \%$ at nine days and 15 days after the treatment (Figure 9B). The percentage of lymphocytes was not significantly altered after the treatment at any time point (Figure 9C). A significant increase in the BALF NO level was observed in the mice treated with $200 \mathrm{mg} / \mathrm{m}^{3}$ of the powder for nine days (Figure 9D).
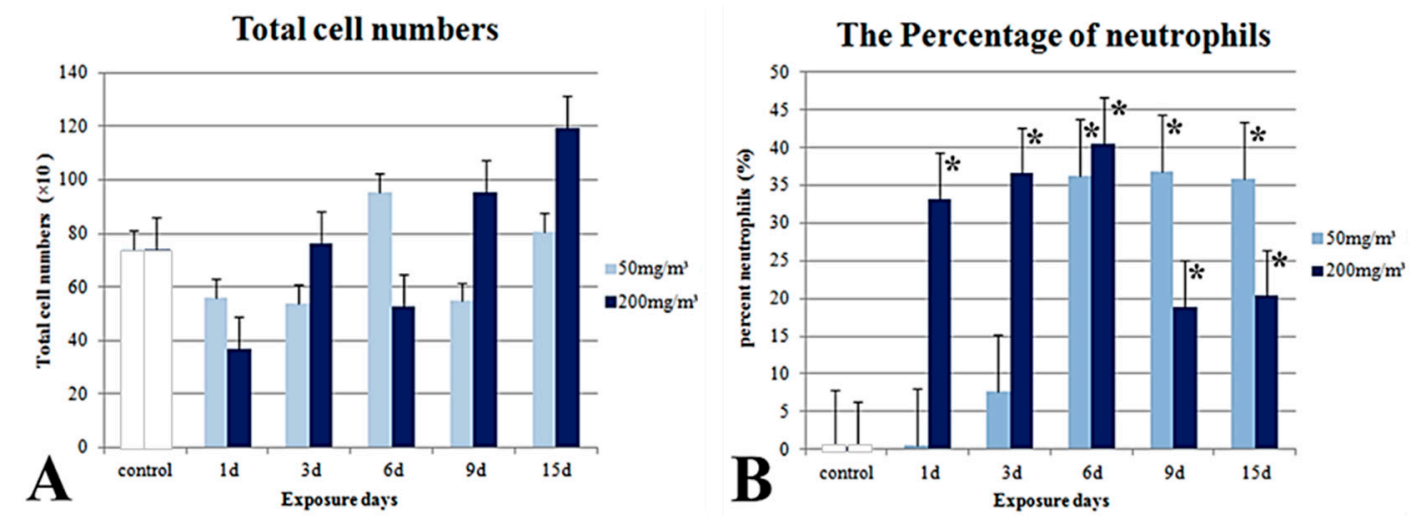

Figure 9. Cont. 
The Percentage of lymphocytes

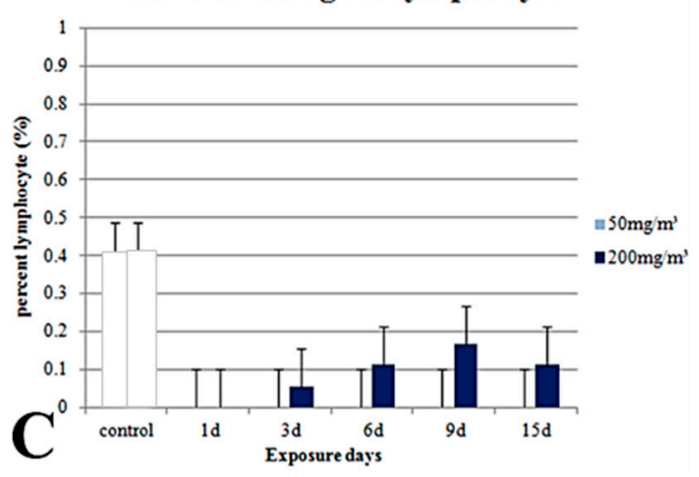

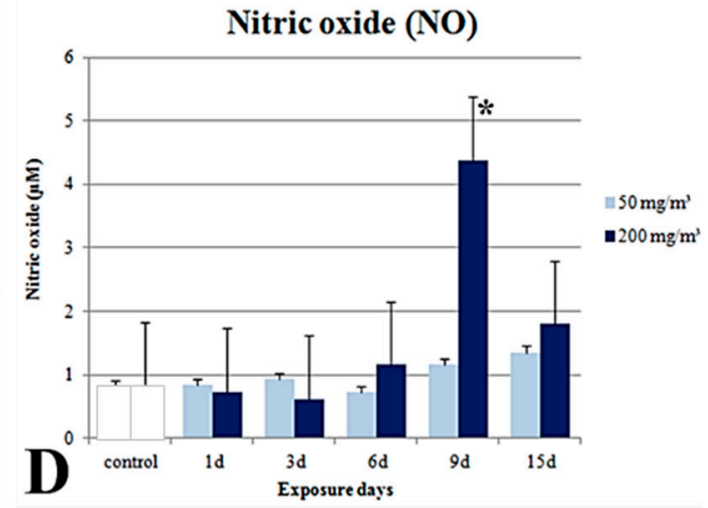

Figure 9. Cellular and biochemical parameters of the bronchoalveolar lavage fluid. Total cell numbers (A); The percentage of neutrophils (B); The percentage of lymphocytes (C); Nitric oxide (D). d: day, * significantly different from the control group, $p<0.05$.

\section{Discussion}

Acute pulmonary toxicity caused by inhalation exposure of Kanto loam powder, which resembles ASD in elemental composition and particle size, was pathologically examined in this study over a period of 1 to 15 days after exposure. In the exposed groups, infiltration of inflammatory cells, dominated by neutrophils and macrophages, was observed in both lung tissues and BALF. Histological sections of the lungs taken from the mice treated with $50 \mathrm{mg} / \mathrm{m}^{3}$ and $200 \mathrm{mg} / \mathrm{m}^{3}$ of the particles showed acute alveolitis consisting of an increased number of particle-containing neutrophils and macrophages, intra-alveolar hemorrhage, exudation of serum protein into the alveolar spaces, and diffuse deposition of particles at the bronchi and in alveolar epithelial cells. The intensity of the inflammatory changes in the lung and the number of neutrophils in the BALF from particle-treated mice appeared to increase with both time after exposure and particle concentration. Acute [22,23] and chronic $[24,25]$ pulmonary toxicity induced by intratracheally-instilled ASD is characterized by purulent inflammation, thickening of alveolar walls, fibrosis, and formation of granulomas. Similar lesions were also reported after experimental inhalation of crystalline silica [16-18,27,28].

In the normal lung tissues, type 1 alveolar epithelial cells and vascular endothelial cells are closely packed together across the basement membrane [29]. In this study, the destruction of the alveolar walls in the inflammatory lesions was observed by electron microscopy. The degeneration and detachment of type 1 alveolar epithelial cells, and the dissociation of the basement membrane between type 1 alveolar cells and endothelial cells were observed in the pulmonary lesions of the mice treated with colloidal silica [30]. These findings suggest that silicon dioxide $\left(\mathrm{SiO}_{2}\right)$, which is the major component of Kanto loam powder, might be, in part, responsible for pulmonary lesion formation.

Laminin, which is present in the pulmonary basement membranes and is used as a marker for normal alveolar structures [31], plays a central role in the stability of basement membranes, as well as in the control of cellular interactions. In this study, inflammatory lesions in the lung tissues showed a decrease in laminin immunopositivity resulting from the destruction of the pulmonary tissues, including the basement membrane. Alpha-SMA is a marker for smooth muscle fibers, as well as myofibroblasts. Myofibroblasts have a role in the repair of injured tissue by producing connective tissue components during the chronic phase of inflammation [32,33]. The increase in $\alpha$-SMA immunopositivity observed in the lung inflammatory lesions in the mice treated with the Kanto loam powder may have been produced in an attempt to repair the tissue.

TNF- $\alpha$ plays important roles in acute inflammation, such as activation of inflammatory cells and induction of secondary tissue injury. The expression of chemokines is modulated by the presence of TNF- $\alpha$ [34]. TNF- $\alpha$ is produced by activated macrophages, lymphocytes, and endothelial cells, as well as other various cell types [35]. IL-6, which has multiple functions, is produced by many 
cell types, such as T lymphocytes, monocytes, endothelial cells, and fibroblasts [36]. The release of inflammatory cytokines, such as TNF- $\alpha$ and IL-6, in pulmonary lesions was observed in animals treated with ASD [22,37], quartz [38], and crystalline silica [39]. In this study, particle-containing macrophages in the inflammatory lesions also stained positively for TNF- $\alpha$ and IL-6. Inflammatory cytokines, including TNF- $\alpha$ and IL-6, may be involved in the development of the inflammatory lesions observed in this study.

$\mathrm{NO}$ and reactive oxygen species are reported to cause severe oxidative stress [17]. In the BALF from rats instilled with crystalline silica, messenger RNA levels of iNOS, an inducible enzyme that produces NO, increased $[40,41]$. The activation of iNOS in the inflammatory cells and the production of NO were reported to be associated with silica-induced damage of the lung [20,42]. In this study, particle-containing macrophages were positive for iNOS immunoreactivity. A significant increase in BALF NO levels was observed in the mice treated with $200 \mathrm{mg} / \mathrm{m}^{3}$ of the powder for nine days. These findings suggest that oxidative stress may be, in part, responsible for the development of acute lung toxicity induced by Kanto loam powder.

\section{Materials and Methods}

\subsection{Animals}

A total of 66 male five-week-old ICR mice were obtained from CLEA JAPAN Inc. (Tokyo, Japan). The animals were fed a diet, CE-2, purchased from CLEA JAPAN and water was given ad libitum. The mouse cages were placed in a conventional room, where the temperature was maintained at approximately $25^{\circ} \mathrm{C}$ and the humidity was maintained at 55 to $70 \%$. All animal experiments were performed according to the Tottori University Guidelines for Animal Welfare (12-T-21, 2 July 2012 http://grc1.med.tottori-u.ac.jp/files/12337.pdf?_=20141007.pdf). Body weight changes were recorded weekly to assess the general health status of the mice.

\subsection{Materials}

The mice were exposed to Kanto loam powder (JIS Z 8901, class 11 ultrafine), obtained from the Association of Powder Process Industry and Engineering (Kyoto, Japan). Kanto loam powder consists of the following: $34-40 \% \mathrm{SiO}_{2}, 26-32 \% \mathrm{Al}_{2} \mathrm{O}_{3}, 0-7 \% \mathrm{MgO}, 17-23 \% \mathrm{Fe}_{2} \mathrm{O}_{3}$, and $0-3 \% \mathrm{CaO}$, with $0-4 \%$ ignition loss. The mean diameter of the particles is approximately $1.6-2.3 \mu \mathrm{m}$ according to the manufacturer's data sheet. ASD particles (CJ-2) contain $28.0 \% \mathrm{Si}, 5.9 \% \mathrm{Al}, 5.3 \% \mathrm{Ca}, 3.0 \% \mathrm{Fe}, 1.7 \% \mathrm{~K}$, and $1.6 \% \mathrm{Mg}$ [23-25], and the mean diameter of the 2010 and 2011 ASD, transported in Korea over long distances, were reported to be 2.5 and $2.9 \mu \mathrm{m}$, respectively [43]; Kanto loam powder resembles ASD in elemental composition and particle size.

\subsection{Study Protocol}

A total of 66 mice were divided into a control group $(n=6)$ and five exposure groups $(n=12)$ as follows: one-day exposure group, three-day exposure group, six-day exposure group, nine-day exposure group, and 15-day exposure group. Each exposure group was divided into two subgroups according to the concentration of Kanto loam powder: a $50 \mathrm{mg} / \mathrm{m}^{3}$ group and a $200 \mathrm{mg} / \mathrm{m}^{3}$ group $[17,26,27]$.

Six mice were placed in an acrylic holder that was attached to the nose-only inhalation exposure apparatus (SIS-C, SIBATA, Soka, Japan) and exposed to Kanto loam powder at concentrations of 50 or $200 \mathrm{mg} / \mathrm{m}^{3}$ for $6 \mathrm{~h}$ a day over $1,3,6,9$, or 15 consecutive days (Figure 10). The test material was generated using a dust feeder (DF-3, SIBATA). The control mice were exposed to clean air. 


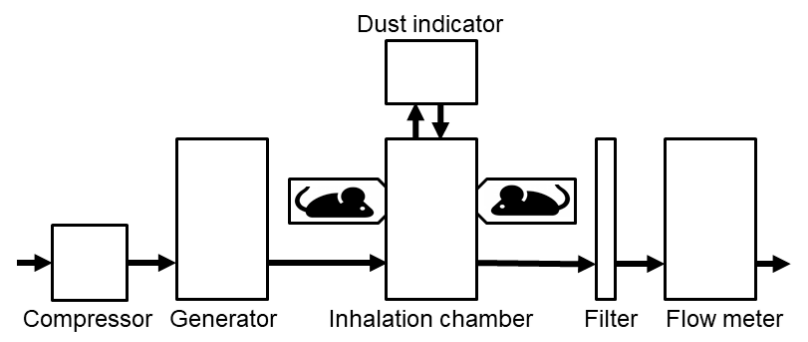

Figure 10. Diagram of the nose inhalation system.

After exposure, the animals were deeply anesthetized by intraperitoneal injection of sodium pentobarbital and killed by exsanguination.

\subsection{Pathological Examination}

A pathological examination was performed on three mice from each group. Portions of the lungs and pulmonary lymph node were fixed by immersion in 10\% neutral-buffered formalin for one day. The formalin-fixed tissues of the lungs and pulmonary lymph node were routinely processed, and embedded in paraffin for histopathological and immunohistochemical examinations. Approximately 3- $\mu$ m-thick sections were cut and stained with hematoxylin and eosin (HE). The pathological examination was performed by two pathologists.

\subsection{Immunohistochemistry}

Paraffin-embedded lung sections from the mice exposed to $50 \mathrm{mg} / \mathrm{m}^{3}$ of the Kanto loam powder or control mice exposed to clean air were used for immunohistochemical detection of alpha smooth muscle actin ( $\alpha$-SMA), laminin, lysozyme, tumor necrosis factor alpha (TNF- $\alpha$ ), interleukin-6 (IL-6), and inducible nitric oxide synthase (iNOS) levels. Antigen retrieval was performed on the sections by incubating in citrate buffer solution $(\mathrm{pH}=5.4)$ and microwaving ( $\alpha$-SMA, IL-6, TNF- $\alpha$, and iNOS) or by treating with protein kinase (laminin, lysozyme). Endogenous peroxidase activity was quenched by immersion in $3 \% \mathrm{H}_{2} \mathrm{O}_{2}$ at room temperature for $30 \mathrm{~min}$. The slides were then blocked with $10 \%$ normal goat serum for $5 \mathrm{~min}$ with microwave treatment. Thereafter, the sections were incubated with the primary antibodies overnight at $4{ }^{\circ} \mathrm{C}$ (anti- $\alpha$-smooth muscle actin, Dako, Glostrup, Denmark, 1:80 dilution; anti-laminin, Dako, 1:2000 dilution; anti-lysozyme, Dako, 1:500 dilution; anti-TNF- $\alpha$, Monosan, Uden, The Netherlands, 1:15 dilution; anti-IL-6, Abcam, Tokyo, Japan, 1:200 dilution; and anti-iNOS, Abcam, Cambridge, UK, 1:100 dilution). The primary antibodies were replaced with phosphate-buffered saline in the negative controls. After incubation with the primary antibodies, peroxidase-labeled polymers conjugated to secondary anti-mouse and anti-rabbit antibodies (En Vision + kit/HRP (DAB), Dako) were applied to the sections for $30 \mathrm{~min}$ at room temperature. The sections were stained with the 3,3'-diaminobenzidine tetrahydrochloride (DAB) as a chromogen, and counterstained with hematoxylin. Positive reactions are indicated by brown staining. In the lungs of mice treated with $50 \mathrm{mg} / \mathrm{m}^{3}$ and $200 \mathrm{mg} / \mathrm{m}^{3}$ of the powder for one day and for 15 days, a semi-quantitative evaluation of the immunohistochemical reactions (TNF- $\alpha$, IL- 6 , iNOS) was conducted by counting the number of stained cells in 10 microscopic fields at $400 \times$. This was performed five times and the mean values were calculated and recorded.

\subsection{Electron Microscopy}

The lung accessory lobes of the mice treated with $50 \mathrm{mg} / \mathrm{m}^{3}$ of the Kanto loam powder were fixed in $10 \%$ neutral phosphate-buffered formalin and examined by electron microscopy. The tissues were trimmed to $1 \mathrm{~mm} \times 1 \mathrm{~mm} \times 1 \mathrm{~mm}$ and post-fixed in $1 \%$ osmium acid fixative. After osmification, the tissues were rinsed in $0.1 \mathrm{M}$ phosphate buffer, dehydrated through a graded ethanol series, transitioned through n-butyl glycidyl ether (QY-1) (Nisshin EM Co., Ltd., Tokyo, Japan), and infiltrated 
and embedded in Quetol-812 epoxy formulation (Nisshin EM Co., Ltd., Tokyo, Japan). Afterward, thick sections were cut, mounted on glass slides, stained with toluidine blue, and examined by light microscopy. Thin sections were mounted on 200-mesh copper fine grids (Nisshin EM Co., Ltd., Tokyo, Japan), and stained with uranyl acetate, followed by post-staining in lead acetate. The sections were then examined using a SU8020 field emission-type scanning electron microscope at $25 \mathrm{kV}$ accelerating voltage (Hitachi Ltd., Tokyo, Japan).

\subsection{Analysis of Bronchoalveolar Lavage Fluid (BALF)}

The BALF from three animals of each group was examined. After euthanasia, the trachea was cannulated, and the lungs were lavaged with three injections of $1.2 \mathrm{~mL}$ saline maintained at $37^{\circ} \mathrm{C}$. The lavage fluid was harvested by gentle aspiration. The three lavage samples were combined into a plastic tube, cooled to $4{ }^{\circ} \mathrm{C}$, and centrifuged at $3000 \mathrm{rpm}$ for $10 \mathrm{~min}$. The supernatants were stored at $-80{ }^{\circ} \mathrm{C}$ until the nitric oxide (NO) analysis was performed. NO was analyzed using a Griess Reagent System (Promega Corporation, Madison, WI, USA) according to the manufacturer's protocol. The total number of cells, cell viability, and differential cell counts were analyzed using the cell pellets. Cell viability was assessed by trypan blue dye exclusion using a hemocytometer chamber. The differential cell counts were assessed on cytology slide preparations. The slides were stained with Diff-Quick (International Regents Corp., Kobe, Japan), and a total of 200 cells were counted using a light microscope.

\subsection{Statistical Analysis}

All data were expressed as mean \pm standard deviation. Statistical analysis of the cellular and biochemical parameters of BALF and immunohistopathological changes was performed using Student's $t$-test for two-group comparisons. For all comparisons, $p$ values less than 0.05 were considered statistically significant.

\section{Conclusions}

This study demonstrated that inhalation exposure of $50 \mathrm{mg} / \mathrm{m}^{3}$ or $200 \mathrm{mg} / \mathrm{m}^{3}$ of Kanto loam powder, which resembles ASD in elemental composition and particle size, caused acute and diffuse inflammatory changes in the lung. The direct effect of the Kanto loam powder and the indirect effects produced by the secondary release of inflammatory cytokines and NO may be responsible for these changes. However, an inhalation exposure experiment using a lower concentration of Kanto loam powder is required.

Acknowledgments: This study was supported in part by a Grant-in-Aid for Scientific Research (S: no. 25220201, C: no. 16K08034) from JSPS KAKENHI and by Joint Research Program of Arid Land Research Center, Tottori University (no. 28C2018).

Author Contributions: Akinori Shimada and Takehito Morita conceived and designed the experiments; Yoshimi Kobayashi performed the experiments; Akinori Shimada, Kenichiro Inoue, Hirohisa Takano and Yoshimi Kobayashi analyzed the data; and Akinori Shimada and Yoshimi Kobayashi wrote the paper.

Conflicts of Interest: The authors declare no conflict of interest. The founding sponsors had no role in the design of the study; in the collection, analyses, or interpretation of data; in the writing of the manuscript; or in the decision to publish the results.

\section{References}

1. Kurosaki, Y.; Shinoda, M.; Mikami, M. What caused a recent increase in dust outbreaks over East Asia? Geophys. Res. Lett. 2011, 38, L11702. [CrossRef]

2. Lin, C.-Y.; Wang, Z.; Chen, W.-N.; Chang, S.-Y.; Chou, C.C.K.; Sugimoto, N.; Zhao, X. Long-range transport of Asian dust and air pollutants to Taiwan: Observed evidence and model simulation. Atmos. Chem. Phys. 2007, 7, 423-434. [CrossRef] 
3. Lee, H.; Kim, H.; Honda, Y.; Lim, Y.H.; Yi, S. Effect of Asian dust storms on daily mortality in seven metropolitan cities of Korea. Atmos. Environ. 2013, 79, 510-517. [CrossRef]

4. Park, Y.S.; Kim, J.H.; Jang, H.J.; Tae, Y.H.; Lim, D.H. The effect of Asian dust on asthma by socioeconomic status using national health insurance claims data in Korea. Inhal. Toxicol. 2016, 28, 1-6. [CrossRef] [PubMed]

5. Yang, C.Y.; Cheng, M.H.; Chen, C.C. Effects of Asian dust storm events on hospital admissions for congestive heart failure in Taipei, Taiwan. J. Toxicol. Environ. Health A 2009, 72, 324-328. [CrossRef] [PubMed]

6. Kashima, S.; Yorifuji, T.; Suzuki, E. Asian dust and daily emergency ambulance calls among elderly people in Japan: An analysis of its double role as a direct cause and as an effect modifier. J. Occup. Environ. Med. 2014, 56, 1277-1283. [CrossRef] [PubMed]

7. Onishi, K.; Otani, S.; Yoshida, A.; Mu, H.; Kurozawa, Y. Adverse health effects of Asian dust particles and heavy metals in Japan. Asia Pac. J. Public Health 2015, 27, 1719-1726. [CrossRef] [PubMed]

8. Mori, I.; Nishikawa, M.; Tanimura, T.; Quan, H. Change in size distribution and chemical composition of Kosa (Asian dust) aerosol during long-range transport. Atmos. Environ. 2003, 37, 4253-4263. [CrossRef]

9. Griffin, D.W. Atmospheric movement of microorganisms in clouds of desert dust and implications for human health. Clin. Microbiol. Rev. 2007, 20, 459-477. [CrossRef] [PubMed]

10. Nishikawa, M.; Quan, H.; Morita, M. Preparation and evaluation of certified reference materials for Asian mineral dust. Glob. Environ. Res. 2000, 1, 103-113.

11. Calvert, G.M.; Rice, F.L.; Boiano, J.M.; Sheehy, J.W.; Sanderson, W.T. Occupational silica exposure and risk of various diseases: An analysis using death certificates from 27 states of the United States. Occup. Environ. Med. 2003, 60, 122-129. [CrossRef] [PubMed]

12. Kim, J.Y.; Do, S.Y.; Moon, Y.H.; Lee, C.G.; Kim, Y.S.; Choi, B.S.; Kim, E.S.; Song, H.S. Systemic sclerosis due to crystalline silica exposure among jewelry workers in Korea: Two case reports. Ann. Occup. Environ. Med. 2017, 29, 18. [CrossRef] [PubMed]

13. Parks, C.G.; Conrad, K.; Cooper, G.S. Occupational exposure to crystalline silica and autoimmune disease. Environ. Health Perspect. 1999, 107, 793-802, PMCID PMC1566238. [CrossRef] [PubMed]

14. Pollard, K.M. Silica, Silicosis, and Autoimmunity. Front. Immunol. 2016, 7, 97. [CrossRef] [PubMed]

15. Langley, R.J.; Mishra, N.C.; Peña-Philippides, J.C.; Hutt, J.A.; Sopori, M.L. Granuloma formation induced by low-dose chronic silica inhalation is associated with an anti-apoptotic response in Lewis rats. J. Toxicol. Environ. Health A 2010, 73, 669-683. [CrossRef] [PubMed]

16. Porter, D.W.; Hubbs, A.F.; Mercer, R.; Robinson, V.A.; Ramsey, D.; McLaurin, J.; Khan, A.; Battelli, L.; Brumbaugh, K.; Teass, A.; et al. Progression of lung inflammation and damage in rats after cessation of silica inhalation. Toxicol. Sci. 2004, 79, 370-380. [CrossRef] [PubMed]

17. Porter, D.W.; Millecchia, L.L.; Willard, P.; Robinson, V.A.; Ramsey, D.; McLaurin, J.; Khan, A.; Brumbaugh, K.; Beighley, C.M.; Teass, A.; et al. Nitric oxide and reactive oxygen species production causes progressive damage in rats after cessation of silica inhalation. Toxicol. Sci. 2006, 90, 188-197. [CrossRef] [PubMed]

18. Sellamuthu, R.; Umbright, C.; Roberts, J.R.; Young, S.H.; Richardson, D.; McKinney, W.; Chen, B.T.; Li, S.; Kashon, M.; Joseph, P. Molecular mechanisms of pulmonary response progression in crystalline silica exposed rats. Inhal. Toxicol. 2017, 29, 53-64. [CrossRef] [PubMed]

19. Friedetzky, A.; Garn, H.; Kirchner, A.; Gemsa, D. Histopathological changes in enlarged thoracic lymph nodes during the development of silicosis in rats. Immunobiology 1998, 199, 119-132. [CrossRef]

20. Porter, D.W.; Millecchia, L.; Robinson, V.A.; Hubbs, A.; Willard, P.; Pack, D.; Ramsey, D.; McLaurin, J.; Khan, A.; Landsittel, D.; et al. Enhanced nitric oxide and reactive oxygen species production and damage after inhalation of silica. Am. J. Physiol. Lung Cell. Mol. Physiol. 2002, 283, L485-L493. [CrossRef] [PubMed]

21. Cox-Ganser, J.M.; Burchfiel, C.M.; Fekedulegn, D.; Andrew, M.E.; Ducatman, B.S. Silicosis in lymph nodes: The canary in the miner? J. Occup. Environ. Med. 2009, 51, 164-169. [CrossRef] [PubMed]

22. Ichinose, T.; Nishikawa, M.; Takano, H.; Sera, N.; Sadakane, K.; Mori, I.; Yanagisawa, R.; Oda, T.; Tamura, H.; Hiyoshi, K.; et al. Pulmonary toxicity induced by intratracheal instillation of Asian yellow dust (Kosa) in mice. Environ. Toxicol. Pharmacol. 2005, 20, 48-56. [CrossRef] [PubMed]

23. Naota, M.; Mukaiyama, T.; Shimada, A.; Yoshida, A.; Okajima, M.; Morita, T.; Inoue, K.; Takano, H. Pathological study of acute pulmonary toxicity induced by intratracheally instilled Asian sand dust (Kosa). Toxicol. Pathol. 2010, 38, 1099-1110. [CrossRef] [PubMed] 
24. Naota, M.; Shiotsu, S.; Shimada, A.; Kohara, Y.; Morita, T.; Inoue, K.; Takano, H. Pathological study of chronic pulmonary toxicity induced by intratracheally instilled Asian sand dust (Kosa). Toxicol. Pathol. 2013, 41, 48-62. [CrossRef] [PubMed]

25. Shimada, A.; Kohara, Y.; Naota, M.; Kobayashi, Y.; Morita, T.; Inoue, K.; Takano, H. Pathological study of chronic pulmonary toxicity induced by intratracheally instilled Asian sand dust (Kosa): Possible association of fibrosis with the development of granulomatous lesions. Folia Histochem. Cytobiol. 2015, 53, 294-306. [CrossRef] [PubMed]

26. Kobayashi, Y.; Shimada, A.; Nemoto, M.; Morita, T.; Adilbish, A.; Bayasgalan, M. Adverse effects of inhaled sand dust particles on the respiratory organs of sheep and goats exposed to severe sand storms in Mongolia. Folia Histochem. Cytobiol. 2014, 52, 244-249. [CrossRef] [PubMed]

27. Castranova, V.; Porter, D.; Millecchia, L.; Ma, J.Y.; Hubbs, A.F.; Teass, A. Effect of inhaled crystalline silica in a rat model: Time course of pulmonary reactions. Mol. Cell. Biochem. 2002, 234, 177-184. [CrossRef] [PubMed]

28. Scabilloni, J.F.; Wang, L.; Antonini, J.M.; Roberts, J.R.; Castranova, V.; Mercer, R.M. Matrix metalloproteinase induction in fibrosis and fibrotic nodule formation due to silica inhalation. Am. J. Physiol. Lung Cell. Mol. Physiol. 2004, 288, 709-717. [CrossRef] [PubMed]

29. Vaccaro, C.A.; Brody, J.S. Structural features of alveolar wall basement membrane in the adult rat lung. J. Cell. Biol. 1981, 91, 427-437. [CrossRef] [PubMed]

30. Kaewamatawong, T.; Kawamura, N.; Okajima, M.; Sawada, M.; Morita, T.; Shimada, A. Acute pulmonary toxicity caused by exposure to colloidal silica: Particle size dependent pathological changes in mice. Toxicol. Pathol. 2005, 33, 745-751. [CrossRef] [PubMed]

31. Gil, J.; Martinez-Hernandez, A. The connective tissue of the rat lung: Electron immunohistochemical studies. J. Histochem. Cytochem. 1984, 32, 230-238. [CrossRef] [PubMed]

32. Darby, I.A.; Zakuan, N.; Billet, F.; Desmoulière, A. The myofibroblast, a key cell in normal and pathological tissue repair. Cell. Mol. Life Sci. 2016, 73, 1145-1157. [CrossRef] [PubMed]

33. Klingberg, F.; Hinz, B.; White, E.S. The myofibroblast matrix: Implications for tissue repair and fibrosis. J. Pathol. 2013, 229, 298-309. [CrossRef] [PubMed]

34. Pryhuber, G.S.; Huyck, H.L.; Baggs, R.; Oberdörster, G.; Finkelstein, J.N. Induction of chemokines by low-dose intratracheal silica is reduced in TNF I (p55) null mice. Toxicol. Sci. 2003, 72, 150-157. [CrossRef] [PubMed]

35. Wajant, H.; Pfizenmaier, K.; Scheurich, P. Tumor necrosis factor signaling. Cell Death Differ. 2003, 10, 45-65. [CrossRef] [PubMed]

36. Tanaka, T.; Kishimoto, T. The biology and medical implications of interleukin-6. Cancer Immunol. Res. 2014, 2, 288-294. [CrossRef] [PubMed]

37. Ichinose, T.; Hiyoshi, K.; Yoshida, S.; Takano, H.; Inoue, K.; Nishikawa, M.; Mori, I.; Kawazato, H.; Yasuda, A.; Shibamoto, T. Asian sand dust aggravates allergic rhinitis in guinea pigs induced by Japanese cedar pollen. Inhal. Toxicol. 2009, 21, 985-993. [CrossRef] [PubMed]

38. Ernst, H.; Rittinghausen, S.; Bartsch, W.; Creutzenberg, O.; Dasenbrock, C.; Görlitz, B.D.; Hecht, M.; Kairies, U.; Muhle, H.; Müller, M.; et al. Pulmonary inflammation in rats after intratracheal instillation of quartz, amorphous $\mathrm{SiO}_{2}$, carbon black, and coal dust and the influence of poly-2-vinylpyridine- $\mathrm{N}$-oxide (PVNO). Exp. Toxicol. Pathol. 2002, 54, 109-126. [CrossRef] [PubMed]

39. Fazzi, F.; Njah, J.; Di Giuseppe, M.; Winnica, D.E.; Go, K.; Sala, E.; St Croix, C.M.; Watkins, S.C.; Tyurin, V.A.; Phinney, D.G.; et al. TNFR1/phox interaction and TNFR1 mitochondrial translocation Thwart silica-induced pulmonary fibrosis. J. Immunol. 2014, 192, 3837-3846. [CrossRef] [PubMed]

40. Blackford, J.A., Jr.; Antonini, J.M.; Castranov, V.; Dey, R.D. Intratracheal instillation of silica up-regulates inducible nitric oxide synthase gene expression and increases nitric oxide production in alveolar macrophages and neutrophils. Am. J. Respir. Cell Mol. Biol. 1994, 11, 426-431. [CrossRef] [PubMed]

41. Huffman, L.J.; Judy, J.; Castranova, V. Regulation of nitric oxide production by rat alveolar macrophages in response to silica exposure. J. Toxicol. Environ. Health Part A 1998, 53, 29-46. [PubMed] 
42. Zeidler, P.; Hubbs, A.; Battelli, L.; Castranova, V. Role of inducible nitric oxide synthase-derived nitric oxide in silica-induced pulmonary inflammation and fibrosis. J. Toxicol. Environ. Health A 2004, 67, 1001-1026. [CrossRef] [PubMed]

43. Jeong, G.Y.; Kim, J.Y.; Seo, J.; Kim, G.M.; Jin, H.C.; Chun, Y. Long-range transport of giant particles in Asian dust identified by physical, mineralogical, and meteorological analysis. Atmos. Chem. Phys. 2014, 14, 505-521. [CrossRef]

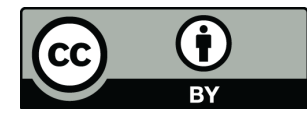

(C) 2018 by the authors. Licensee MDPI, Basel, Switzerland. This article is an open access article distributed under the terms and conditions of the Creative Commons Attribution (CC BY) license (http:/ / creativecommons.org/licenses/by/4.0/). 